\title{
Introduction
}

The cultural historian Peter Gay called the 19th century - the long period of peace in Europe from 1815 to 1914 - Schnitzler's Century. In fact, Arthur Schnitzler, who was born in 1862, 4 years before Austria was humiliatingly defeated by the Prussian military machine at the battle of Sadowa, and died in 1931, 7 years before the beguiling myth of Viennese brilliance finally lost its veneer with Hitler's Anschluss, lived his entire life in the long twilight of the Habsburg dynasty. He is one of those representative 19th-century figures who experienced the disorder and difficulty of the modern era but could still recall, sometimes long-windedly or with pompous ease, how things were in the old days - when people still believed in freedom and the individual.

Like his near-contemporary Chekhov, Schnitzler began his professional life as a physician and became well-known as a boulevard playwright. In his lifetime, his name was a by-word for success and scandal. His play Reigen (The Dance of Love or, Merry-Go-Round) had to be pulled from the stage, and caused riots in Berlin. In 10 skilfully interlinked dialogues, later turned into the memorable film La Ronde by Max Ophuls (1951), Schnitzler methodically

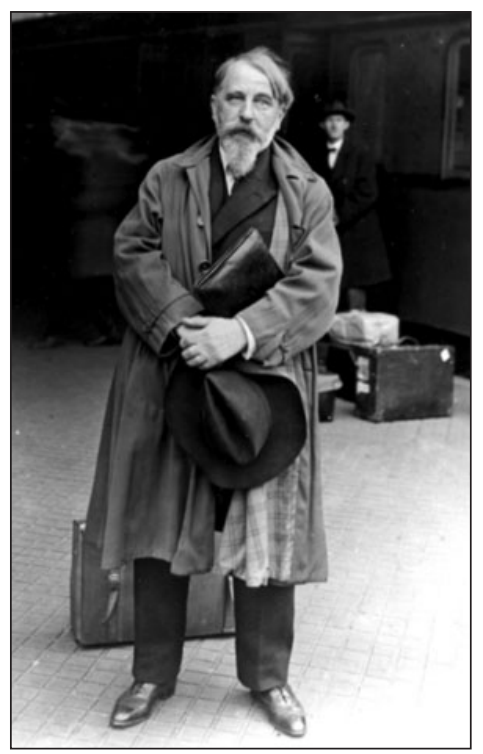

examined how lovers change place. That kind of outspokenness about the erotic and affective, in a society that was generally genteel and evasive about such matters, brings out the parallel between Schnitzler and Freud: for a long time, it was assumed that the former had been one of the earliest undeclared disciples of the latter after his ambitious Three Essays on the Theory of Sexuality (1905). In fact, as Peter Gay remarks, Freud, who was no flatterer of his contemporaries, had nothing but praise for Schnitzler, referring to him as his 'psychic twin' and confessing in a birthday letter that he had long wondered how the artist had been able to plumb the obscure depths of the psyche without having to do the 'laborious research' incumbent about the psychoanalyst.

After the collapse of the Habsburg monarchy (and his market) and in the darkening anti-Semitic mood of the late 1920s, Schnitzler turned increasingly to short fiction and the diary; he would not have been surprised to learn that the Nazis burned his books barely 2 years after his death.

Sometimes rather analytical - Schnitzler noted that he was more interested in 'cases' than in individuals - his stories sometimes lack the more genial literary waywardness of Chekhov: The Son, for example, is impressive for demonstrating, in the manner of a psychological study on crime and punishment (or guilt and expiation), how the mother continues to 'smother' her son, though with boundless affection, and in so doing punishes herself more cruelly than any court. As Freud would have it, the guilty person always finds a way of punishing herself. Yet it is the doctor-narrator who is most discomfited: his 'positivist' understanding of personality leaves him no way to understand a course of action that is both admirable, and destructive. Egotism never had a more clinical exponent than Schnitzler.

For all Schnitzler's old-fashioned naturalism, it is in his prose that interior monologue first emerged as a sustained literary technique, in the novella Fräulein Else (1924). The further narrative goes behind the frontal bone, the more circumstances work to impose their agenda. Schnitzler's work also insists that feelings and understanding, though they might live in the same house, keep separate beds.

The doubts about the comprehensiveness of agency at the end of The Son are recognisable from Freud's writings too, as well as anticipating those of our own half-medicalised, half-eroticised era. Stanley Kubrick's instincts were right when he looked for a script for his notaltogether successful last film Eyes Wide Shut (1999) and found in it Traumnovelle (1926); Schnitzler's sense for the libidinal energies of the city lights, the social atavisms behind respectable masks, and the weight of unreality is still with us.

Clive James, in his latest bumper book Cultural Amnesia, also claims Schnitzler as one of the literary greats. James' famous wit, it emerges, has nourished itself on Schnitzler's almost unknown book of aphorisms, Book of Thoughts and Sayings, of which a small sample is presented on pages 1010-1011. Levity, it would appear, requires a lifetime of effort; and even then you still don't know if you're just fooling around, or have reached what earlier ages used to call wisdom.

\section{lain Bamforth}

More recent translations of Arthur Schnitzler's work in English include:

Night Games and Other Stories and Novellas (2002)

Desire and Delusion: Three Novellas (2003) Bachelors: Novellas and Stories (2006)

All translated by Margaret Schaefer, and published by Ivan R Dee, Chicago

Dream Fantasia, translated by JMQ Davies, with an introduction by Frederic Raphael, Penguin (1999)

Round Dance and Other Plays, translated by JMQ Davies, with an introduction by Ritchie Robertson, Oxford University Publishing (2004). 